\title{
Trends in precipitation: analysis of long annual and monthly time series from mainland Portugal
}

\author{
M. I. P. de Lima ${ }^{1,2}$, S. C. P. Carvalho ${ }^{1}$, J. L. M. P. de Lima ${ }^{1,3}$, and M. F. E. S. Coelho ${ }^{4}$ \\ ${ }^{1}$ IMAR - Marine and Environmental Research Centre, Portugal \\ ${ }^{2}$ Department of Forest Resources/ESAC, Polytechnic Institute of Coimbra, Bencanta, 3040-316 Coimbra, Portugal \\ ${ }^{3}$ Department of Civil Engineering, Faculty of Science and Technology, Campus II - University of Coimbra, 3030-788 \\ Coimbra, Portugal \\ ${ }^{4}$ Institute of Meteorology, Rua C ao Aeroporto, 1749-077 Lisboa, Portugal
}

Received: 4 November 2009 - Revised: 3 May 2010 - Accepted: 4 May 2010 - Published: 10 June 2010

\begin{abstract}
The purpose of this work is to investigate trends in annual and monthly precipitation in mainland Portugal by studying long time series. The data are from ten measuring stations scattered over mainland Portugal; some of the time series date back from the 19th century. Trends in these precipitation series were examined using the Mann-Kendall non-parametric trend test and the Sen's nonparametric method. Both full monotonic trends (i.e., over the record period) and partial trends were investigated. Results provide no evidences for rejecting the null hypothesis of no trend in annual precipitation, when a monotonic linear model was used. On the other hand, the analyses of partial trends in the time series identified a sequence of alternating decreasing and increasing trends in annual precipitation, which are sometimes statistically significant. This type of behaviour was also observed for the monthly precipitation.
\end{abstract}

\section{Introduction}

The impact of climate change on precipitation is one of the major concerns in many scientific research studies (e.g. Wentz et al., 2007; Zhang et al., 2007). Variations in precipitation over different time-scales are expected to affect the water resources system, in particular because precipitation drives other hydrological processes (e.g. surface flow, groundwater flow). Thus, it is crucial to investigate the recent changes in precipitation patterns that are claimed by different studies and to understand those changes as part of the

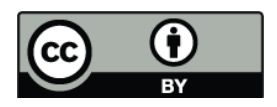

Correspondence to: M. I. P. de Lima (iplima@esac.pt) long term behaviour of this process. Quite often the limiting factor is the short length of many existing precipitation records; the majority of the studies on this topic are based on relatively short time series, covering a few decades, over periods of about $40-50$ years. Only a few studies report results for longer periods. For the Iberian Peninsula, Lionello et al. (2006) give an interesting review of several studies of precipitation trends. Many trend studies focus on the second half of the 20th century (i.e. 50 years), or even on smaller periods; for example, Mosmann et al. (2004), use the period 1961-1990. Only a few studies cover the 20th century as a whole. The debate about the different results that are sometimes reported triggered the study presented here, where the main purpose is to complement previous studies for mainland Portugal (e.g. de Lima et al., 2007, reporting trend analysis of annual and monthly point precipitation data from 19412000 , for 107 stations scattered over the territory) by investigating precipitation trends in mainland Portugal using the longest records available. Furthermore, numerical models of climate change prediction over the Iberian Peninsula (see e.g. Miranda et al., 2006) are in need of further insight. This study explores the statistical analyses of annual and monthly precipitation, searching for the presence of linear monotonic trends in the temporal structure of precipitation.

\section{Precipitation data}

Ten precipitation data sets from mainland Portugal were studied; the location of the measuring sites is shown in Fig. 1. The records were obtained by the Institute of Meteorology (IM) and the Institute for Water (INAG), of Portugal. The data comprised time series of annual and monthly resolutions, spanning periods that range between 88 and 145 years.

Published by Copernicus Publications on behalf of the European Geosciences Union. 
Table 1. Some descriptive statistics for the annual time series, and linear monotonic (full record period) and partial trends given by the Sen's estimator of the slope (mm/decade). The confidence levels for the trend tests are marked: $+90 \%$ and $* * 99 \%$.

\begin{tabular}{|c|c|c|c|c|c|c|c|c|}
\hline \multirow{2}{*}{$\begin{array}{l}\text { Measuring } \\
\text { Station }\end{array}$} & \multirow[b]{2}{*}{ Period } & \multicolumn{4}{|c|}{ Annual precipitation } & \multirow{2}{*}{$\begin{array}{l}\text { Monotonic Trends } \\
\text { Sen's slope } \\
(\mathrm{mm} / \mathrm{dec})\end{array}$} & \multicolumn{2}{|c|}{ Partial Trends } \\
\hline & & $\begin{array}{r}\text { Mean } \\
(\mathrm{mm})\end{array}$ & $\begin{array}{l}\text { Coef. of } \\
\text { variation }\end{array}$ & $\begin{array}{l}\text { Maximum } \\
(\mathrm{mm})\end{array}$ & $\begin{array}{l}\text { Minimum } \\
(\mathrm{mm})\end{array}$ & & $\begin{array}{l}\text { Sub- } \\
\text { period }\end{array}$ & $\begin{array}{r}\text { Sen's slope } \\
(\mathrm{mm} / \mathrm{dec})\end{array}$ \\
\hline Lisboa & $1871-2007$ & 733.3 & 0.250 & 1421 & 416 & -2.61 & $\begin{array}{l}1933-1963 \\
1963-1983\end{array}$ & $\begin{array}{l}70.54^{+} \\
-74.40\end{array}$ \\
\hline Porto & $1863-2007$ & 1236.8 & 0.251 & 2255 & 604 & -3.35 & $\begin{array}{l}1947-1967 \\
1967-2002\end{array}$ & $\begin{array}{r}222.33 \\
52.88\end{array}$ \\
\hline Coimbra & 1900-1998 & 982.3 & 0.216 & 1651 & 524 & -1.75 & $\begin{array}{l}1946-1966 \\
1966-1992\end{array}$ & $\begin{array}{r}204.85 \\
-68.71\end{array}$ \\
\hline Évora & $1871-2007$ & 629.2 & 0.253 & 1186 & 346 & -3.78 & $\begin{array}{l}1942-1981 \\
1981-2001\end{array}$ & $\begin{array}{r}-8.23 \\
44.83\end{array}$ \\
\hline Beja & 1900-2007 & 563.4 & 0.246 & 1042 & 301 & -2.92 & $\begin{array}{l}1933-1961 \\
1961-1981\end{array}$ & $\begin{array}{r}67.28 \\
-66.31\end{array}$ \\
\hline Lagos & $1902-2006$ & 527.4 & 0.302 & 1098 & 187 & 7.15 & $\begin{array}{l}1941-1961 \\
1961-1981\end{array}$ & $\begin{array}{r}116.67^{+} \\
-105.11^{+}\end{array}$ \\
\hline $\begin{array}{l}\text { São Brás } \\
\text { de Alportel }\end{array}$ & 1909-2002 & 836.8 & 0.306 & 1693 & 431 & 12.78 & $\begin{array}{l}1935-1962 \\
1962-1982\end{array}$ & $\begin{array}{r}75.60 \\
-139.24\end{array}$ \\
\hline Travancas & 1914-2006 & 984.5 & 0.252 & 1636 & 499 & -4.32 & $\begin{array}{l}1940-1960 \\
1960-1981\end{array}$ & $\begin{array}{r}164.67 \\
-78.80\end{array}$ \\
\hline Moncorvo & $1878-1995$ & 568.8 & 0.263 & 1095 & 253 & -3.78 & $\begin{array}{l}1945-1965 \\
1965-1989\end{array}$ & $\begin{array}{r}164.60^{* *} \\
-25.30\end{array}$ \\
\hline Penha Garcia & 1911-1998 & 808.0 & 0.264 & 1597 & 432 & -5.64 & $\begin{array}{l}1945-1965 \\
1965-1993\end{array}$ & $\begin{array}{r}140.33^{+} \\
-56.33\end{array}$ \\
\hline
\end{tabular}

Table 1 presents some descriptive statistics for the annual time series.

Mainland Portugal is geographically located in the transitional region between the sub-tropical anticyclone and the sub-polar depression zones, between latitudes $42^{\circ} 09^{\prime}$ and $36^{\circ} 56^{\prime} \mathrm{N}$ and longitudes $9^{\circ} 34^{\prime}$ and $6^{\circ} 10^{\prime} \mathrm{W}$. Its climate is much influenced by the latitude, the orography and the proximity to the Atlantic Ocean. The climatic variables exhibit strong north-south and west-east gradients, and precipitation also exhibits strong seasonal variability. The dominant climate in mainland Portugal is mild Mediterranean with a warm, dry summer period. These characteristics are more pronounced in the south.

\section{Methodology}

This section is dedicated to giving a brief overview of the methodology used in data analyses.

Firstly, statistical tests were used to investigate the annual data for normality and relative homogeneity. The ShapiroWilk and the Kolmogorov-Smirnov non-parametric normality tests were applied (see e.g. Royston, 1982, and Deheuvels, 1981). The four tests selected to check the time series homogeneity are described in Wijngaard et al. (2003):
Standard Normal Homogeneity Test, Buishand range test, Pettitt test and Von Neumann ratio test. Three of these tests are able to locate the change-point.

The presence of trends in the long precipitation time series was examined using the Mann-Kendall non-parametric test (e.g. Gilbert, 1987). This test does not assume any particular form for the unknown distribution function; it is based on ranks within the time series. The test is useful whenever the possible trend (which is associated with long range persistence) can be considered monotonic. The null hypothesis $H_{0}$ of no trend (i.e the observations are randomly ordered in time) is tested against the alternative hypothesis, $H_{1}$, associated with increasing or decreasing monotonic trends. In this work the null hypothesis is tested at the 10, 5, 1 and $0.1 \%$ significance level; the test was taken in its two-sided form (see e.g. Sneyers, 1990).

The Sen's non-parametric method (e.g. Gilbert, 1987) can be used for estimating the change per unit time in processes that exhibit linear trends.

To deal with the non-monotonic character of trends in the data, the method described by Tomé and Miranda (2005) was used. It aims at fitting to a time series an unknown number of continuous straight-line segments and at defining the instants of change in the properties of the data; see also Tomé 


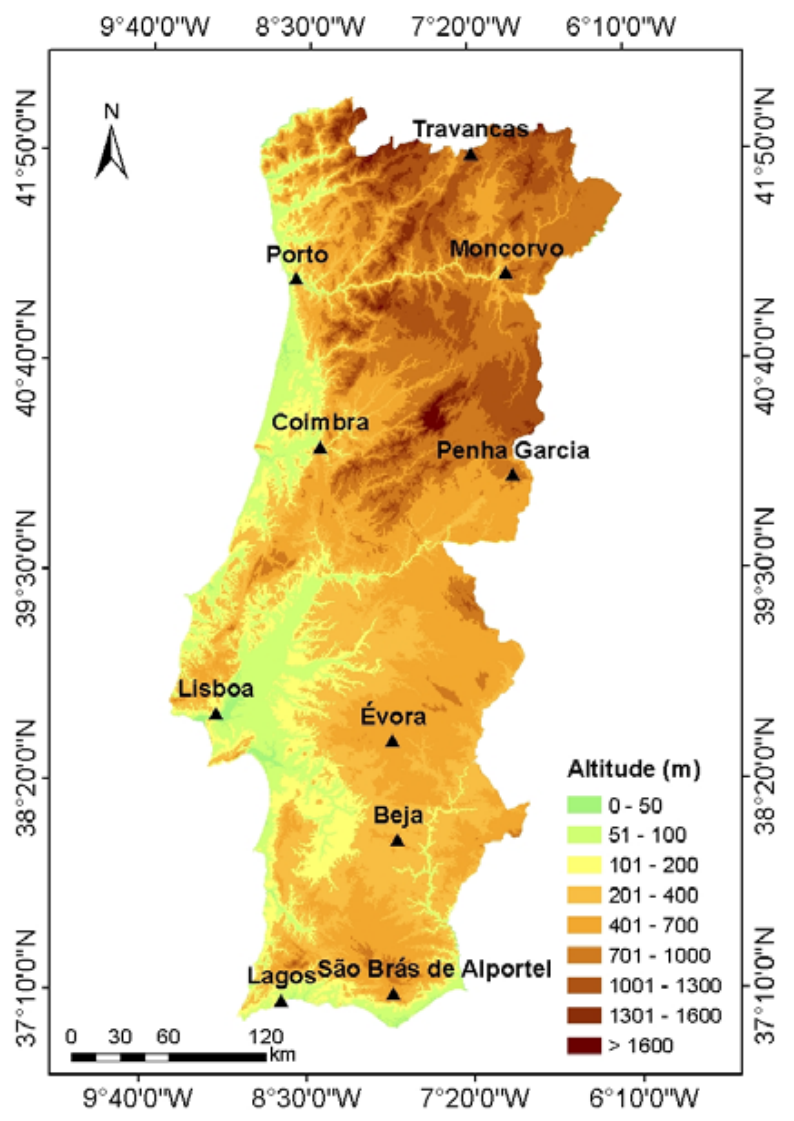

Fig. 1. Location of ten precipitation measuring stations in mainland Portugal.

and Miranda (2004). Thus, the method searches for such segments that fit the data best, in a least-square sense, while satisfying two other conditions: a minimum time distance between breakpoints and a minimum trend change at each breakpoint. These two conditions are pre-set by the user.

\section{Results}

\subsection{Annual precipitation}

The statistics of the Shapiro-Wilk and Kolmogorov-Smirnov tests, applied to the annual precipitation time series, provided evidences to reject the null hypothesis of normality for only one data set: São Brás de Alportel.

In relation to the results of the homogeneity tests, almost all data sets were classified as "useful"; the only exception was the data set from São Brás de Alportel which was classified as "doubtful". The classification is based on the results of the homogeneity tests at the $1 \%$ significance level (see details on the methodology in Wijngaard et al., 2003). The available metadata do not allow identifying hypothetical changes in instrumentation and location of the measuring stations. Nevertheless, over the full record period, the data

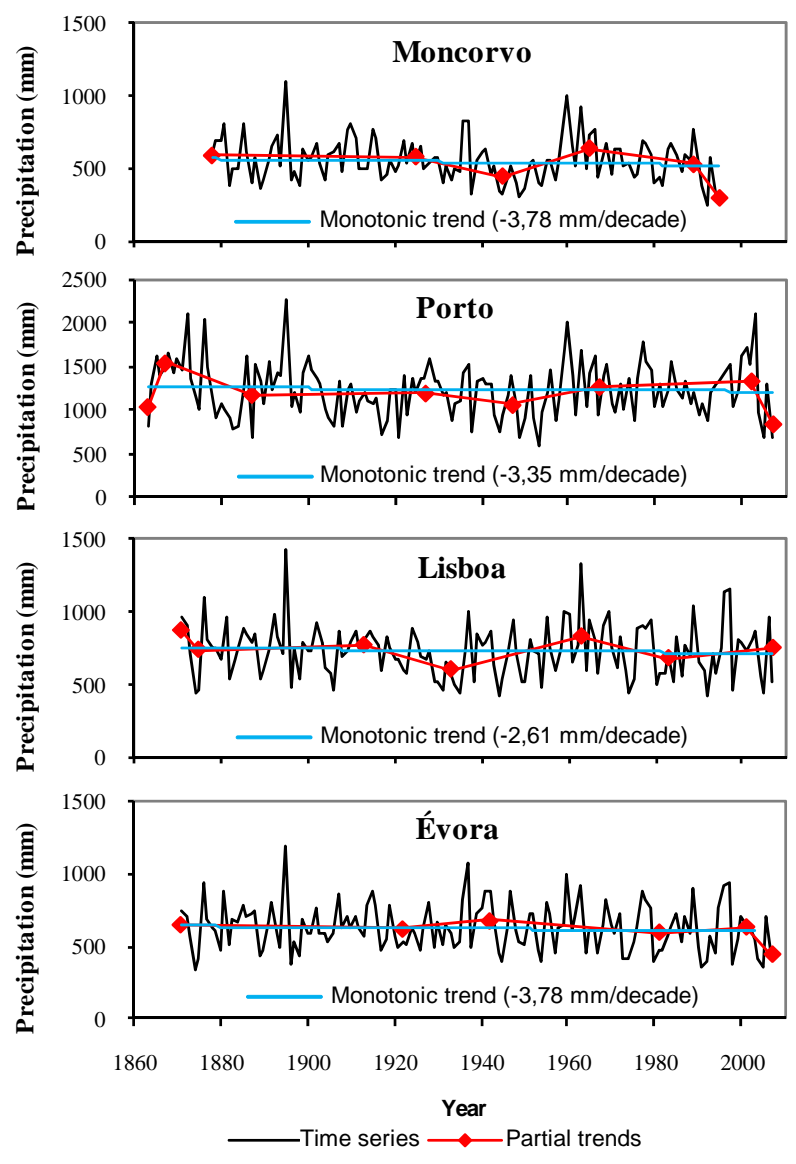

Fig. 2. Annual precipitation series from mainland Portugal, and linear monotonic and partial trends. The Sen's estimator of the slope of the monotonic trends over the full record periods are indicated in the legend.

showed some signatures of no homogeneity. However, for the sub-periods analyzed for partial trends (below), all the precipitation series were categorized "useful".

Results of the annual precipitation trend analyses are given in Table 1 and Fig. 2. Figure 2 shows the annual time series for selected locations, the monotonic linear trend fitting to the data and the partial trends identified using the method described by Tomé and Miranda (2005). The statistical significance of the results was assessed using the Mann-Kendall test and was determined at the 10, 5, 1 and $0.1 \%$ levels (see Table 1). Over the full time span of the records, there were no evidences to reject the null hypothesis of no trend in annual precipitation at any of the stations.

The method used to investigate partial trends identifies times of significant change in the precipitation series. The results obtained by imposing a minimum rate of change at consecutive breakpoints of $0.01 \mathrm{~mm} /$ year, a minimum allowed interval between breakpoints of 20 years, and a minimum allowed length of 5 years for the first and last segments are shown in Figs. 2 and 3, for annual precipitation. It is possible 


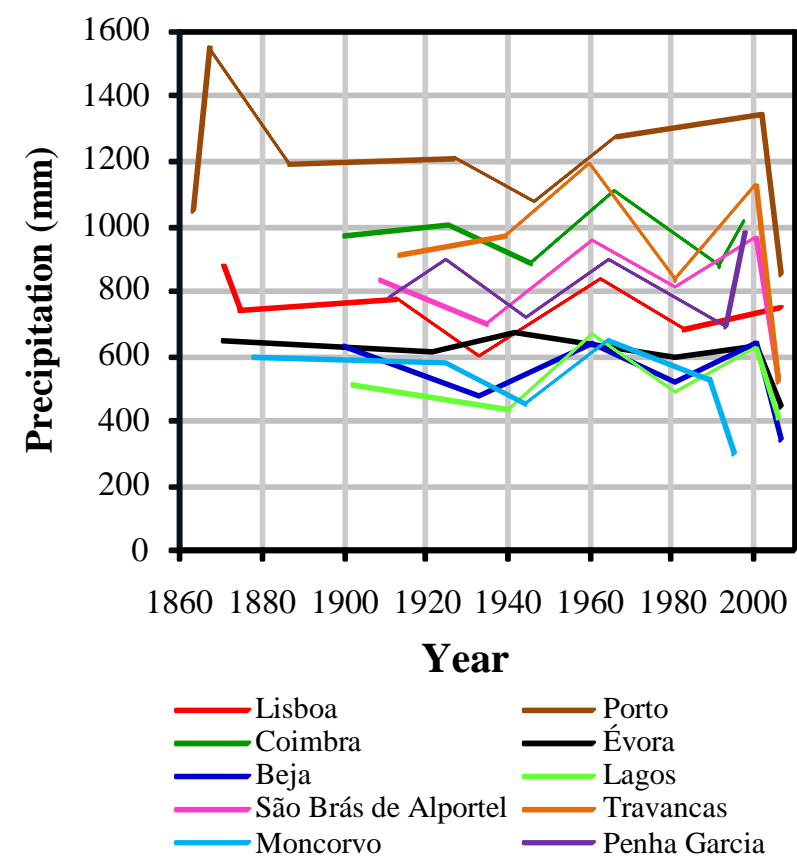

Fig. 3. Partial trends in annual precipitation from mainland Portugal. The breakpoints were estimated using the method proposed by Tomé and Miranda (2005). The time series are not plotted.

that, in certain cases, these conditions may introduce some bias in the results; in particular, the location of the breakpoints (i.e. times of significant change) can be affected.

As revealed by Fig. 3, the patterns of precipitation variation over time have not been the same for all the data sets investigated. The very low spatial density provided by these long time series make it difficult to evaluate the influence of local factors (e.g. topographical factors) on the results. The plots in Fig. 3 highlight that sub-periods of increasing and decreasing trends in annual precipitation are present in the records, and that often they alternate over time. For each data set two such consecutive periods were selected, and the magnitude of the corresponding (partial) trend is given in Table 1; it shows how different the result analyses can be depending on the period studied. Also, from data set to data set, there are some small shifts in the corresponding breakpoints. Nevertheless, there is a common pattern: the alternation of periods of increasing and decreasing trends in annual precipitation. However, the length of the time series does not allow for a satisfactory characterization of the frequency associated to this behaviour; the minimum of 20 years between breakpoints can be explained by one of the conditions imposed to the automatic search for times of significant change in the precipitation series. Please note that the first and last segments are too short to allow for a reliable estimation of trend since this estimator could easily be biased.

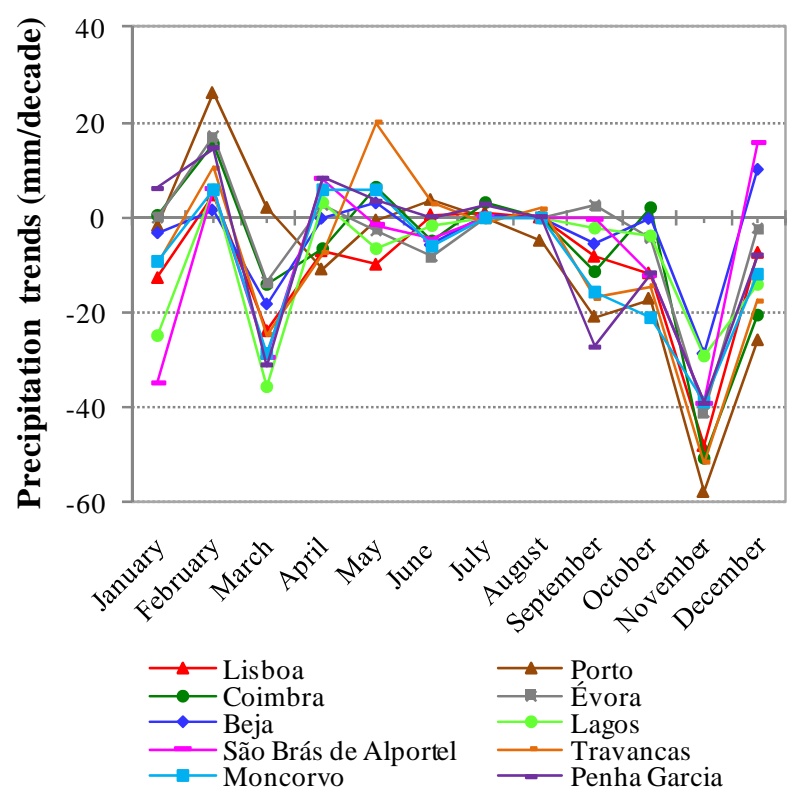

Fig. 4. Monthly precipitation trends in the common period 1960 1980, which corresponds roughly to a period of decreasing annual trend for most of the 10 locations studied.

\subsection{Monthly precipitation}

Results of the analysis of trends in monthly precipitation are shown in Table 2. The study of the full record period do not suggest overall important changes in precipitation distribution over the year. The exception, which is particularly notable, is the precipitation in March: over time spans ranging from 88 to 145 years, the precipitation in March exhibits a decreasing trend in all the ten stations investigated; for seven of the data sets the trends are statistically significant at least at the $5 \%$ level.

However, the investigation of sub-periods leads to different results. An example is given in Table 2 for the period from roughly 1960 to 1980 , when a decreasing trend in annual precipitation was observed. This behaviour and the subperiods that are indicated in Table 2 were identified by conducting partial trend analysis of the available data (check Table 1). Please note that the selected sub-periods reported in Table 2 are not exactly the same for all the data sets, which can explain some of the differences obtained for the rate of change in monthly precipitation observed at the different locations, apart from local factors.

For the common period 1960-1980, the monthly trends are illustrated in Fig. 4. During this period almost all results point out to a reduction in monthly precipitation during mid autumn and winter over mainland Portugal, which occurred more strongly in the months of November, December and January. Note that not all the results are statistically significant at the 5\% level. Studies reporting changes in seasonal precipitation for the Iberian Peninsula highlight that 
Table 2. Sen's estimator of the monthly precipitation trends (mm/decade) and the respective confidence levels: $+90 \%,{ }^{*} 95 \%,{ }^{* *} 99 \%$ and *** $99.9 \%$. The data are for the full period and for periods of negative trend in annual precipitation, which were selected for each time series based on the breakpoints located in the partial trend analyses.

\begin{tabular}{|c|c|c|c|c|c|c|c|c|c|c|c|c|c|}
\hline $\begin{array}{l}\text { Station } \\
\text { name }\end{array}$ & Period & Jan & $\mathrm{Feb}$ & Mar & Apr & May & Jun & Jul & Aug & Sep & Oct & Nov & Dec \\
\hline Lisboa & $\begin{array}{l}1871-2007 \\
1963-1983\end{array}$ & $\begin{array}{r}0.89 \\
-\mathbf{7 3 . 2 9}^{*}\end{array}$ & $\begin{array}{r}-0.64 \\
-35.93\end{array}$ & $\begin{array}{r}-\mathbf{2 . 8 3}^{* *} \\
-23.68\end{array}$ & $\begin{array}{r}-1.13 \\
7.00\end{array}$ & $\begin{array}{r}-0.47 \\
2.64\end{array}$ & $\begin{array}{l}-0.36 \\
-3.64\end{array}$ & $\begin{array}{r}0.00 \\
1.59^{*}\end{array}$ & $\begin{array}{l}0.02 \\
0.00\end{array}$ & $\begin{array}{l}-0.08 \\
-3.54\end{array}$ & $\begin{array}{l}-0.35 \\
-6.58\end{array}$ & $\begin{array}{r}-0.29 \\
-22.79\end{array}$ & $\begin{array}{r}-0.63 \\
8.58\end{array}$ \\
\hline Porto & $\begin{array}{l}1863-2007 \\
1927-1947\end{array}$ & $\begin{array}{l}0.84 \\
0.29\end{array}$ & $\begin{array}{l}0.68 \\
6.00\end{array}$ & $\begin{array}{r}-2.52 \\
-47.54\end{array}$ & $\begin{array}{r}-0.89 \\
2.44\end{array}$ & $\begin{array}{l}-0.04 \\
-3.39\end{array}$ & $\begin{array}{l}-0.57 \\
-5.17\end{array}$ & $\begin{array}{l}-0.17 \\
-9.61\end{array}$ & $\begin{array}{r}0.31 \\
-3.19\end{array}$ & $\begin{array}{r}-0.24 \\
-14.91\end{array}$ & $\begin{array}{r}-0.97 \\
7.64\end{array}$ & $\begin{array}{r}-0.82 \\
-20.75\end{array}$ & $\begin{array}{r}1.85 \\
-53.41\end{array}$ \\
\hline Coimbra & $\begin{array}{l}1900-1998 \\
1966-1992\end{array}$ & $\begin{array}{r}4.13 \\
-\mathbf{4 2 . 2 4}\end{array}$ & $\begin{array}{r}1.25 \\
-28.50\end{array}$ & $\begin{array}{r}-6.41^{* *} \\
-11.80\end{array}$ & $\begin{array}{r}-0.10 \\
10.69\end{array}$ & $\begin{array}{r}2.10 \\
-\mathbf{2 2 . 7 5}^{+}\end{array}$ & $\begin{array}{r}0.02 \\
-1.91\end{array}$ & $\begin{array}{l}-0.25 \\
-0.33\end{array}$ & $\begin{array}{r}-0.17 \\
2.00\end{array}$ & $\begin{array}{l}-0.58 \\
-2.62\end{array}$ & $\begin{array}{r}0.79 \\
18.54\end{array}$ & $\begin{array}{l}-1.10 \\
-9.38\end{array}$ & $\begin{array}{r}-1.02 \\
13.05\end{array}$ \\
\hline Évora & $\begin{array}{l}1871-2007 \\
1942-1981\end{array}$ & $\begin{array}{r}-0.07 \\
2.66\end{array}$ & $\begin{array}{r}-0.63 \\
16.42^{*}\end{array}$ & $\begin{array}{c}-2.15^{*} \\
-14.11^{+}\end{array}$ & $\begin{array}{l}-0.85 \\
-3.68\end{array}$ & $\begin{array}{r}-0.77 \\
0.30\end{array}$ & $\begin{array}{r}-0.45 \\
3.50\end{array}$ & $\begin{array}{l}0.00 \\
0.00\end{array}$ & $\begin{array}{l}0.00^{+} \\
-0.05\end{array}$ & $\begin{array}{l}0.21 \\
1.06\end{array}$ & $\begin{array}{r}0.32 \\
-2.67\end{array}$ & $\begin{array}{l}-1.24 \\
-5.59\end{array}$ & $\begin{array}{l}-0.07 \\
-4.00\end{array}$ \\
\hline Beja & $\begin{array}{l}1900-2007 \\
1961-1981\end{array}$ & $\begin{array}{r}0.19 \\
-14.89\end{array}$ & $\begin{array}{l}-0.81 \\
-6.37\end{array}$ & $\begin{array}{r}-\mathbf{3 . 2 5}^{* *} \\
-13.53\end{array}$ & $\begin{array}{l}0.17 \\
3.58\end{array}$ & $\begin{array}{r}-0.54 \\
6.13\end{array}$ & $\begin{array}{r}-0.26 \\
-11.33\end{array}$ & $\begin{array}{l}0.00 \\
0.17\end{array}$ & $\begin{array}{l}0.00 \\
0.10\end{array}$ & $\begin{array}{r}0.05 \\
-4.58\end{array}$ & $\begin{array}{l}1.44 \\
3.22\end{array}$ & $\begin{array}{r}-1.51 \\
-\mathbf{3 2 . 4 4}^{*}\end{array}$ & $\begin{array}{r}0.33 \\
17.79\end{array}$ \\
\hline Lagos & $\begin{array}{l}1902-2006 \\
1961-1981\end{array}$ & $\begin{array}{r}0.18 \\
-40.62\end{array}$ & $\begin{array}{r}-0.08 \\
9.39\end{array}$ & $\begin{array}{r}-1.15 \\
-\mathbf{2 9 . 1 2}^{*}\end{array}$ & $\begin{array}{l}0.74 \\
5.98\end{array}$ & $\begin{array}{l}-0.07 \\
-1.86\end{array}$ & $\begin{array}{r}-0.11^{+} \\
-4.55\end{array}$ & $\begin{array}{r}0.00 \\
0.00^{*}\end{array}$ & $\begin{array}{r}0.00^{+} \\
0.00\end{array}$ & $\begin{array}{r}0.00 \\
-1.91\end{array}$ & $\begin{array}{r}1.66 \\
-3.10\end{array}$ & $\begin{array}{r}-0.70 \\
-\mathbf{4 9 . 0 8}^{*}\end{array}$ & $\begin{array}{r}1.33 \\
-14.19\end{array}$ \\
\hline $\begin{array}{l}\text { São Brás } \\
\text { de Alportel }\end{array}$ & $\begin{array}{l}1909-2002 \\
1962-1982\end{array}$ & $\begin{array}{r}4.35 \\
-56.14\end{array}$ & $\begin{array}{r}-2.88 \\
-28.07\end{array}$ & $\begin{array}{l}-\mathbf{5 . 1 6} \\
-20.73\end{array}$ & $\begin{array}{l}1.42 \\
3.10\end{array}$ & $\begin{array}{r}1.00 \\
-2.38\end{array}$ & $\begin{array}{r}0.00 \\
-11.97\end{array}$ & $\begin{array}{r}0.00^{* * *} \\
0.22^{* *}\end{array}$ & $\begin{array}{r}0.00^{* *} \\
0.00\end{array}$ & $\begin{array}{r}\mathbf{1 . 1 8}^{* * *} \\
2.00\end{array}$ & $\begin{array}{r}0.95 \\
-14.15\end{array}$ & $\begin{array}{r}-1.16 \\
-33.54\end{array}$ & $\begin{array}{l}\text { 8.92* } \\
13.81\end{array}$ \\
\hline Travancas & $\begin{array}{l}1914-2006 \\
1960-1981\end{array}$ & $\begin{array}{r}-1.56 \\
-24.17\end{array}$ & $\begin{array}{r}-2.97 \\
0.80\end{array}$ & $\begin{array}{c}-\mathbf{5 . 3 0}^{+} \\
-23.20\end{array}$ & $\begin{array}{l}-1.13 \\
-1.94\end{array}$ & $\begin{array}{r}-0.49 \\
22.52\end{array}$ & $\begin{array}{l}-1.20 \\
-0.58\end{array}$ & $\begin{array}{r}0.06 \\
-1.56\end{array}$ & $\begin{array}{c}0.92^{*} \\
-0.40\end{array}$ & $\begin{array}{r}0.48 \\
-10.50\end{array}$ & $\begin{array}{c}\mathbf{7 . 0 0}^{* *} \\
-7.14\end{array}$ & $\begin{array}{r}-1.18 \\
-\mathbf{5 8 . 0 0}\end{array}$ & $\begin{array}{l}-4.36 \\
-3.81\end{array}$ \\
\hline Moncorvo & $\begin{array}{l}1878-1995 \\
1965-1989\end{array}$ & 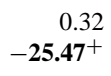 & $\begin{array}{r}0.12 \\
-15.52\end{array}$ & $\begin{array}{l}-\mathbf{2 . 0 3} * \\
-14.77\end{array}$ & $\begin{array}{r}-0.99 \\
12.25\end{array}$ & $\begin{array}{l}-0.53 \\
-3.92\end{array}$ & $\begin{array}{l}0.13 \\
3.49\end{array}$ & $\begin{array}{l}0.00 \\
0.00\end{array}$ & $\begin{array}{l}0.00 \\
0.00\end{array}$ & $\begin{array}{r}-0.57 \\
0.02\end{array}$ & $\begin{array}{r}-1.56 \\
3.72\end{array}$ & $\begin{array}{r}-1.52 \\
5.18\end{array}$ & $\begin{array}{r}-0.14 \\
18.10\end{array}$ \\
\hline Penha Garcia & $\begin{array}{l}1911-1998 \\
1965-1993\end{array}$ & $\begin{array}{r}2.72 \\
-\mathbf{3 5 . 2 2}^{+}\end{array}$ & $\begin{array}{r}0.74 \\
-26.29\end{array}$ & $\begin{array}{r}-10.90^{* * *} \\
-7.39\end{array}$ & $\begin{array}{l}0.06 \\
7.25\end{array}$ & $\begin{array}{l}1.75 \\
0.04\end{array}$ & $\begin{array}{l}-0.40 \\
-3.84\end{array}$ & $\begin{array}{l}0.00 \\
0.00\end{array}$ & $\begin{array}{l}0.00 \\
0.00\end{array}$ & $\begin{array}{l}0.00 \\
0.05\end{array}$ & $\begin{array}{r}0.07 \\
12.77\end{array}$ & $\begin{array}{l}-0.14 \\
-2.53\end{array}$ & $\begin{array}{l}0.00 \\
7.97\end{array}$ \\
\hline
\end{tabular}

the results in terms of increasing and decreasing trends are influenced by the period analyzed and geographical location, which shows that local factors can play an important role in the behaviour observed.

Overall, these results suggest that the distribution of precipitation over the year changes over time. When the data from the particular months were investigated for partial trends, results exhibited an overall presence of alternating decreasing and increasing trends, which is a type of pattern that was also observed for annual precipitation.

\section{Conclusions}

In general, the analyses of the historical precipitation records did not provide statistical evidence for rejecting the null hypothesis of no trend in annual precipitation in mainland Portugal, when the monotonic linearity of trends was tested over the full record period. Thus, no generalized significant long term pattern of change has been found. However, the analyses of partial trends in the time series identified a sequence of alternating periods of decreasing and increasing trends in both annual and monthly precipitation, which are sometimes statistically significant. Results suggest that redistributions of precipitation during the year took place over several decades. There are evidences that both global and local factors might affect the spatial distribution of trends in mainland Portugal, which has been also reported in the literature for other locations in the Iberian Peninsula.
The findings in this study stress that when long records are available, the characterization of trends based on a monotonic (linear) model can be of intrinsic interest but, at the same time, can be meaningless for the evaluation of the behaviour of the process in the near future. However, the analyses of short precipitation records consisting of only a few decades, can be biased by the period studied.

Acknowledgements. This work was carried out under research project PTDC/GEO/73114/2006, funded by the Portuguese Foundation for Science and Technology of the Portuguese Ministry of Science, Technology and Higher Education (Lisbon, Portugal). The authors thank Spyros Athanasatos for his thoughtful support regarding this publication.

Edited by: S. C. Michaelides

Reviewed by: two anonymous referees

\section{References}

de Lima, M. I. P., Marques, A. C. P., de Lima, J. L. M. P., and Coelho, M. F. E. S.: Precipitation trends in Mainland Portugal in the period 1941-2000, IAHS Publ. 310, International Association of Hydrological Sciences, 94-102, 2007.

Deheuvels, P. A.: Kolmogorov-Smirnov type test for independence and multivariate samples, Rev. Roum. Math. Pure A., 26, 213 226, 1981.

Gilbert, R. O.: Statistical methods for environmental pollution monitoring. John Wiley \& Sons, New York, USA, 1987. 
Lionello, P., Malanotte-Rizzoli, P., and Boscolo, R.: Mediterranean climate variability. Developments in earth and environmental sciences, vol. 4, Elsevier, The Netherlands, 2006.

Miranda, P. M. A., Valente, M. A., Tomé, A. R., Trigo, R., Coelho, F., Aguiar, A., and Azevedo, E. B.: O clima de Portugal nos séculos XX e XXI. In: Alterações climáticas em Portugal: Cenários, impactos e medidas de adaptação - Projecto SIAM II, edited by: Santos, F. D. and Miranda, P., Gradiva, Lisbon, Portugal, 506 p., 2006 (in portuguese).

Mosmann, V., Castro, A., Fraile, R., Dessens, J., and Sánchez, J. L.: Detection of statistically significant trends in the summer precipitation of mainland Spain, Atmos. Res., 70(1), 43-53, 2004.

Royston, P.: An extension of Shapiro and Wilk's W test for normality to large samples, App. Statist., 31, 115-124, 1982.

Sneyers, R.: On the statistical analysis of series of observations. Technical Note no. 143, WMO no. 145, World Meteorological Organization, Geneva, Switzerland, 1990.
Tomé, A. R. and Miranda, P. M. A.: Piecewise linear fitting and trend changing points of climate parameters, Geophys. Res. Lett., 31, L02207, doi:10.1029/2003G019100, 2004.

Tomé, A. R. and Miranda, P. M. A.: Continuous partial trends and low-frequency oscillations of time series, Nonlinear Proc. Geoph., 12(4), 451-460, 2005.

Wentz, F. J., Ricciardulli, L., Hilburn, K., and Mears, C.: How much more rain will global warming bring?, Science, 317, 233-235, 2007.

Wijngaard, J. B., Klein-Tank, A. M. G., and Können, G. P.: Homogeneity of 20th century European Daily Temperature and Precipitation Series, Int. J. Climatol., 23, 679-692, 2003.

Zhang, X., Zwiers, F. W., Hegerl, G. C., Lambert, F. H., Gillett, N. P., Solomon, S., Scott, P. A., and Nozawa, T.: Detection of human influence on twentieth-century precipitation trends, Nature, 448, 461-465, doi:10.1038/nature06025, 2007. 